\title{
TITLE:
}

\section{INVERTEBRATE FAUNA OF THE INTERTIDAL ZONE OF THE TOKARA ISLANDS -IV. PRELIMINARY LIST OF THE COLLECTION OF BRACHYURA AND STOMATOPODA-}

\author{
$\operatorname{AUTHOR}(\mathrm{S}):$ \\ Tokioka, Takasi
}

\section{CITATION:}

Tokioka, Takasi. INVERTEBRATE FAUNA OF THE INTERTIDAL ZONE OF THE TOKARA ISLANDS -IV. PRELIMINARY LIST OF THE COLLECTION OF BRACHYURA AND

STOMATOPODA-. PUBLICATIONS OF THE SETO MARINE BIOLOGICAL LABORATORY 1953, 3(2): 141-143

ISSUE DATE:

1953-12-20

URL:

http://hdl.handle.net/2433/174475

RIGHT: 


\section{INVERTEBRATE FAUNA OF THE INTERTIDAL ZONE OF THE TOKARA ISLANDS}

\section{PRELIMINARY LIST OF THE COLLECTION OF BRACHYURA AND STOMATOPODA ${ }^{122)}$}

TAKASI TOKIOKA

Seto Marine Biological Laboratory, Sirahama

With one Text-figure

The collection of crabs is submitted to Dr. T. SAKAI for his investigation, who will publish a complete report. Here, I give preliminarily the list of some easily identified species in the present collection with some brief notes on their habitats.

\section{BRACHYURA}

Dromiacea

1. Petalomera fukuii SAKAI (Takarazima, 2 individuals) Oxystomata

2. Calappa hepatica Linné (Takarazima)

3. Calappa gallus (HeRBst) (Takarazima)

Brachygnatha-Oxyrhyncha

4. Elamena truncata (STIMPSON) (Nakanosima)

5. Micippa platipes RüPPELL (Takarazima)

6. Tiarinia cornigera LATREILLE The dead shells are found very commonly stranded along the coast of Takarazima, while they are rather rare in Nakanosima.

Brachygnatha-Brachyrhyncha

7. Neptunus (Neptunus) sanguinolentus (HERBST) A chela was found in Takarazima.

8. Charybdis orientalis DANA (Nakanosima)

1) Scientific Survey of the Tokara Islands, Report No. 5.

2) Contributions from the Seto Marine Biological Laboratory, No. 211.

Publ. Seto Mar. Biol. Lab., III (2), 1953. (Article 12) 
9. Thalamita stimpsoni A. M. EDWARDS The carapace is greenish when alive. (Takarazima and Nakanosima, in the latter it was met with rather frequently.)

10. Thalamita picta STIMPson The carapace is sandy in colour when alive. (Nakanosima)

11. Thalamita integra DANA (Takarazima, stranded)

12. Carpilius maculatus LINNÉ (Takarazima)

13. Zozymus aeneus (LINNÉ) (Takarazima)

14. Daira perlata (HERBsT) (Takarazima, a stranded carapace)

15. Xantho (Leptodius)) exaratus (M. EDWARDS) (Takarazima, a standed carapace)

16. Xantho (Leptodius) sanguineus (M. EDWARDs)(The dead shells are very numerously stranded along the coasts of Takarazima and Nakanosima)

17. Xantho sp. (Nakanosima)

18. Paraxanthias notatus (DANa) (Nakanosima, 2 individuals)

19. Carpilodes rugatus (M. EDWARDS) Carapace purplish when alive. (Takarazima)

20. Actaea tomentosa (M. EDWARDS) (Takarazima)

21. Actaea consobrina A. M. Edwards (Nakanosima)

22. Etisus (Etisoides) splendidus (RATHBun) (Piece of carapace, Nakanosima)

23. Phymodius ungulatus (H. M. EDWARDS) (Takarazima, an individual)

24. Ozius rugulosus STIMPSON (Takarazima \& Nakanosima)

25. Epixanthus frontalis (M. EDWARDS) (Common in Takarazima)

26. Epixanthus corrosus A. M. EDWARDs (Nakanosima)

27. Lydia annulipes (M. EDWARDs) (The dead shells are common in Takarazima, only an individual in Nakanosima)

28. Eriphia laevimana LATREILLE The eyes red and the carapace grayish violet when alive. (Common in both Takarazima and Nakanosima)

29. Eriphia scabricula DaNa (Common in Takarazima, fewer in Nakanosima)

30. Dacryopilumnus rathbunae BALss (Takarazima)

31. Pilumnus vespertilio FABRICIUs (Takarazima)

32. Ocypoda sp. (In the sandy beach near Ôgomori of Takarazima)

33. Euplax sp. (In the sandy heaps on the reef of Nakanosima.)

34. Grapsus grapsus tenuicrustatus (HERBST) (A cast-off shell in Nakanosima)

35. Grapsus strigosus HERBST The carapace is somewhat greenish and transversely striped with thin purplish brown bands. (Numerous in Takarazima, common in Nakanosima)

36. Geograpsus crinipes (DANA) (Takarazima)

37. Geograpsus lividus stormi DE MAN (An individual from Takarazima, chela in Nakanosima)

38. Pachygrapsus crassipes RANDALl (Nakanosima) 
39. Pachygrapsus minutus A. M. EDWARds (Very numerous in both Takarazima and Nakanosima)

40. Pachygrapsus plicatus (M. EDWARDs) (A cast-off shell in Takarazima)

41. Eriocheir japonicus DE HAAN (Nakanosima)

42. Ptychognathus sp. (Nakanosima)

43. Plagusia depressa tuberculata LAMARCK (Takarazima and Nakanosima)

44. Percnon planissimum (Herbst) (Takarazima and Nakanosima)

\section{STOMATOPODA}

1. Gonodactylus chiragra FABRICIUS Common in both Takarazima and Nakanosima. The body is usually pale yellowish brown and sprinkled with dark spots. Some specimens are, however, uniformly coloured dark green. (TK. Nos. 55-57).
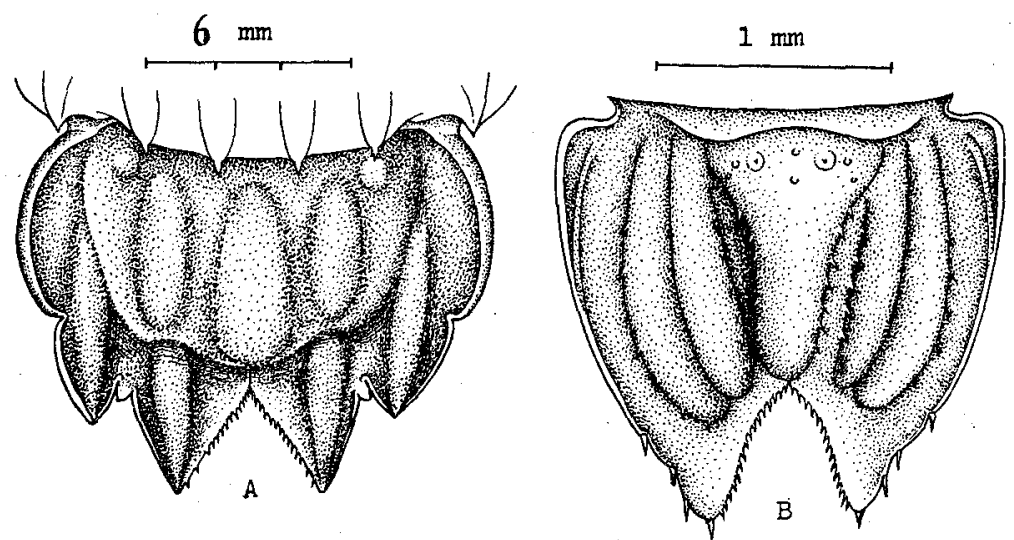

Fig. 1. Telson of Gonodactylus chiragra FABRICIUS (A) and G. glabrous BROOKs, $16 \mathrm{~mm}$ long individual (B).

2. Gonodactylus glabrous Brooks Only two small individuals were collected in Takarazima. (TK. No. 58).

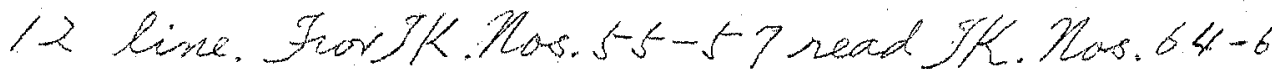

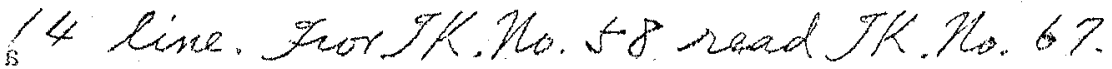

